\title{
RISK MANAGEMENT AND PROFITABILITY OF COMMERCIAL BANKS OF WESTERN BALKANS COUNTRIES OF KOSOVO, ALBANIA, NORTH MACEDONIA, AND SERBIA
}

\author{
Sevdie Alshiqi \\ University of Prishtina "Hasan Prishtina”, Republic of Kosovo \\ Arbana Sahiti \\ University of Prishtina "Hasan Prishtina”, Republic of Kosovo
}

\begin{abstract}
Due to their importance, commercial banks currently play a significant role in national financial systems. Commercial banks' profitability depends on how they manage their loans, and credit risk management is thus crucial in the banking system. Risk management is a significant activity of the commercial bank. This study's primary purpose is to observe the extent to which bank profitability is dependent on credit risk management, with a focus on commercial banks in the Western Balkans (Kosovo, Albania, North Macedonia, and Serbia).

Determinants of profitability, as return on assets (ROA) and return on equity (ROE). Simultaneously, the ratio of non-performing loans (NLPR) and Capital Insufficiency (CAR) are taken as determinants of credit risk management. The research included 45 banks located in the Balkan countries (Kosovo, Albania, Macedonia, and Serbia) for six years, the period 2013-2019. The results reveal a specific assured correlation among credit risk as well as the profitability of banks, where the ratio of non-performing loans (NLPR) has a positive effect on return on equity (ROE) and return on assets (ROA). Capital Insufficiency (CAR) shows that positive dependence is without any statistical significance on return on equity (ROE) and return on assets (ROA).
\end{abstract}

Keywords: banking, credit, ROE, ROA, Risk Management, Western Balkans

DOI: http://dx.doi.org/10.15549/jeecar.v8i1.633

\section{THEORETICAL BACKGROUND}

The countries of the Western Balkans (Kosovo, Albania, North Macedonia, and Serbia) are the countries that were part of the former Socialist Federal Republic of Yugoslavia. The former
Yugoslavia began to break up in the 1990's following political conflicts and wars in the Balkan Peninsula. As a result of the war, these countries have different levels of economic development. They faced these crises, the transition process, and the global economic 
crisis of 2008. According to the World Bank (2018), these countries have economic growth prospects and are well-capitalised, and their commercial banks are competitive with banks in the European Union countries.

In Kosovo, Albania, North Macedonia, and Serbia, deposits are the primary sources of financing for commercial banks. Recently, lending in these countries increased rapidly, particularly in the trade sector. Lending in these countries has never been as vital as it is today; loans are the primary source of financing for purchasing goods and services. This has led to an increase in the number of non-performing loans. Although various reforms have been instituted, there are still high levels of nonperforming loans. This has caused the quality of loan portfolios to decline and negatively affecting the performance of banks.

There are a considerable number of empirical studies related to risk management in banking. From the available literature, we have elaborated on several empirical studies from various countries around the world. Risk management is a special challenge for commercial banks. Success in this function lies in the commitment of assets and their returns according to structured strategic and operational dynamics. Kosovo's banking sector is relatively young compared to the more developed countries in the region and across Europe. In this regard, for effective risk management, the entire banking system must have a sound and stable base (Afroz, 2019).

The sensitivity of the credit risk management process is experienced by commercial banks operating in developing countries. However, the same sensitivity has been and continues to be experienced by commercial banks in developed countries. In the United States (US), to increase the quality of risk management in banking, high standards have been set regarding accounting information and increase control responsibility. To this end, the Sarbanes Oxley Act was adopted in 2002.

Oldfield \& Santomero (1997), in their study of risk management across financial organizations, concluded that 'there are four steps to positive risk management: define financial reporting standards, position restrictions, and rules, create guidelines for strategic investments, and establish incentive contracts and compensation.

Many researchers have noted that there is a difference between the management of assets and liabilities of banks, and, at the same time, there is a positive relationship between deposit ratios and liquidity risk. In market competition, banking risk is based on the size and the formation of its risk management (Niinimäki, 2004). Competition in the sector has resulted in more and more banks contending for deposits, which increases the risk. In this situation, with a high level of savings, banks may feel forced to take extreme risks.

The global financial upheaval of the 1990s occurred due to fundamental mistakes being made in risk management; Barings Bank in London is a case in point. According to Haselmann and Wachtel (2006), research on credit risk factors has been continuous but limited by a lack of data. Fan \& Shaffer (2004), in their study of the relationship between efficiency and risk in large US banks, endow that earnings efficiency is almost conscious to bankruptcy risk and credit risk, which, in turn, is not perceptive to loan-product-portfolio as well as liquidity risk (Yuqi, 2007). A thriving banking system must be operated based on a successful evaluation and methodology of the financial system (Sobolieva-Tereshchenko \& Zhukova, 2020). Sakilu \& Kibret (2015), in the study of financial performance in commercial banks, as a practice of Ethiopian internal governance, have concluded that employees with previous experience in banking, compensation, and risk management committee have adverse effects on performance. For their successful performance, Russian banks applied a month ahead of their lending rates, compared to banks in other countries, which applied five months to respond to monetary policy (Nguyen, Khoi, \& Williams, 2017). Khambata \& Bagdi (2003) considered credit risk in 20 of the largest banks in Japan. Their results showed that adding monetary benefits were mainly used in four banks. This indicates that credit responsibility is the main initiator of credit risk in the traditional balancesheet design. In the United Arab Emirates, Hassan Al-Tamimi et al. (2007) found that the main methods used in banking risk management were creating a unified standard, analysis, evaluation, results, and loan 
guarantees. The authors Vovchak et al. (2019) have studied the risk factors for modelling nonperforming loan-level buildings. They have concluded that the modelling successfully assesses solvency and that credit problems have been shown to exist in a small number of banks, especially in individual loans. The credit risk management process is assisted and controlled by national and international regulators to create a sustainable banking sector. According to Mathuva (2009), studies related to credit risk have traditionally been based on financial reports to assess return on assets (ROA) and capital and measure profitability. Financial statements remain one of the most useful and reliable tools for banking-risk analysis and assessment.

\section{The hypothesis of this study}

There are many methods used in the literature to research the existing links between bank size and credit risk. We will apply the same methods and analyse the dependence of credit risk on specific internal factors. Explanatory variables that have been used to validate the hypotheses are the size of the banks, return on equity (ROE), return on assets (ROA), the ratio of nonperforming loans (NLPR), and capital insufficiency (CAR).

After identifying the research problem, we set the research objectives and addressed the five hypotheses formulated based on the research questions. We have treated the verification of a hypothesis through two sub-hypotheses:
$\left(\mathrm{H}_{0}\right)$ - Which represents the problem statement, and

$\left(\mathrm{H}_{1}\right)$ - indicating the opposite of $\mathrm{H}_{0}$.

In order to achieve the purpose of the study, we have put forward two hypotheses:

$\mathrm{H}_{01}$ - There is a correspondence among Capital Insufficiency - CAR, the ratio of non-performing loans - NLPR and return on Equity - ROE, of commercial banks

$\mathrm{H}_{02}$ - There is a correspondence among Capital Insufficiency - CAR, the ratio of non-performing loans - NLPR and return on assets ROA, of trading counters

\section{Methodology}

This study's primary purpose is to examine the importance and influence of determinants that affect the benefit of trading banks in the Western Balkans (Kosovo, Albania, North Macedonia, and Serbia). The study collected secondary data of 45 banks for the period 20132019 with a total of 315 observations. To conduct the analysis, we conducted a multiple regression using the variables Return on Equity, Return on Assets, Capital Insufficiency, and the ratio of non-performing loans and the banks' size.

As indicated in Table 1, Return on Equity and Return on Assets was used as the dependent variables. In contrast, Capital Insufficiency and the ratio of non-performing loans were used as the independent variables, and the majority of banks were used as the control variable.

Table 1: Explanation of determinants

\begin{tabular}{|l|l|l|}
\hline & Determinants title & Devious title \\
\hline \multirow{2}{*}{ Dependent factors } & Return on Assets & net income/ total asset \\
\cline { 2 - 3 } & Return on Equity & net income/ total equity \\
\hline \multirow{3}{*}{ Independent factors } & Capital Insufficiency & Total capital/RWAs \\
\cline { 2 - 3 } & $\begin{array}{l}\text { The ratio of non- } \\
\text { performing loans }\end{array}$ & NPLR NPLs/total loans \\
\hline Control Factors & Size Bank & Natural logarithm of total assets of banks \\
\hline
\end{tabular}

\section{Linear regression analyzes}

In the following paragraphs, we provide descriptive statistics of variables and their correlations. Regression analysis is a method to find a functional relationship (model or equation) between the response of dependent variables and independent variables (Fumo \& Rafe Biswas, 2015). If only one variable is taken 
as the answer, the analysis is a simple regression analysis (Fumo \& Rafe Biswas, 2015). In linear regression analysis, many parameters can be included that predict the combined effect of the parameters on the result (Pandis, 2016). This analysis is also known as multilinear regression analysis. Regression techniques show the values which $\mathrm{Y}$ predicts from the values of $\mathrm{X}$.

The model in multiple linear regression allows more than one predictor variable. The equations of multiple linear regressions are:

$$
\begin{aligned}
& \text { ROEt }=\grave{\alpha}+\text { CARt }+ \text { NPLt LNTAt } \\
& \text { ROAt }=\grave{\alpha}+\text { CARt }+ \text { NPLt LNTAt }
\end{aligned}
$$

That:

- ROE is the return on equity at time $t$

- ROA is the return on assets at time $t$
- CAR is the capital adequacy ratio at time $t$

- NPLR is the non-performing loan ratio at time $\mathrm{t}$

- LNTA is the natural register of total assets of banks.

\section{Descriptive analysis of the study}

Descriptive statistics are about categorising and describing data to draw conclusions about that data. In the field of data, we look for useful relationships in information or models, especially those relevant to future events. Table 2 sets out the descriptive statistics - the average and standard deviation of the components CAR, NPLR, LNTA, ROA, and ROE - of 45 trading banks in the Western Balkans from 2013 to 2019.

Table 2: Descriptive analysis table of variables

\begin{tabular}{|l|r|r|r|r|r|}
\hline \multicolumn{1}{|c|}{ Factors } & \multicolumn{1}{c|}{ N } & \multicolumn{1}{c|}{ Min } & \multicolumn{1}{c|}{ Max } & \multicolumn{1}{c|}{ Mean } & Std. dev. \\
\hline CAR\% & 315 & 6.9 & 34.8 & 14.2 & 3.66 \\
\hline NLPR\% & 315 & 1.04 & 16.21 & 2.89 & 2.5 \\
\hline LNTA & 315 & 3.72 & 7.88 & 6.17 & 0.93 \\
\hline ROA\% & 315 & -1.85 & 3.68 & 0.26 & 0.58 \\
\hline ROE\% & 315 & -72.5 & 39.4 & 5.15 & 11.38 \\
\hline
\end{tabular}

Source: authors' calculation

In Table 2, the performance of banks is measured by the variables ROE and ROA, while the determinants of risk management are CAR and NPLR. There were 315 observations in this study. According to descriptive statistics, the ROE has a broader distribution than the other variables, with a standard deviation of 11.38 . From the presented data, we see that other indicators have a lower level of deviation. The highest difference in the ROE ratio is $39.4 \%$, and the smallest, $72.5 \%$. From these data, we can conclude that there is substantial variation in the banks' reported ROE in this study.

\section{Granger Causality test}

To further examine the cause-effect relationships among variables, we use the Granger causality test. The Granger causality test is the test used in empirical data to investigate whether there is a linkage between two variables over a period of time. So it is a hypothesis test, which tells us if the variable is essential for predicting another (Wei, 2016). This test shows if one variable causes the trigger against the other variable. To test the linear regression model, we use the Granger causality test using formulas:

$$
\left(X n+\left.1 \in A\right|^{\prime} \Omega n\right) \neq\left(X n+\left.1 \in A\right|^{\prime} \Omega n-Y n\right)
$$

$Y t$ - variables suspected to be causally connected

' $\Omega t$ - all the knowledge available in the Universe on $t$

\section{Testing of variables through correlation}

Before doing the regression analysis, we test the variables through correlation analysis. The correlation coefficient indicates whether the variables are related to each other. The correlation coefficient is otherwise called the 
linear coefficient or the Pearson coefficient. Based on the correlation test, we obtain preliminary information about the variables and analyse their relationship. According to researchers, if the correlation coefficient's value is greater than 0.8 , then it can be said that there is a correlation between the variables. We use the Pearson coefficient to test the hypotheses resulting from the initial correlation analysis. We test ROE and ROA as dependent variables in relation to independent variables CAR, NLPR, and LNTA.

Table 3: Association matrix about regression 1 (ROE)

\begin{tabular}{|l|r|r|r|r|}
\hline & \multicolumn{1}{|c|}{ CAR } & \multicolumn{1}{c|}{ NPLR } & \multicolumn{1}{l|}{ LNTA } & \multicolumn{1}{l|}{ ROA } \\
\hline CAR & 1 & & & \\
\hline NPLR & -0.082 & 1 & & \\
\hline LNTA & 0.0276 & -0.053 & 1 & \\
\hline OE & -0.0286 & -0.2318 & -0.1832 & 1 \\
\hline
\end{tabular}

Table 4: Association matrix about regression 2 (ROA)

\begin{tabular}{|l|r|r|r|r|}
\hline & \multicolumn{1}{|c|}{ CAR } & \multicolumn{1}{|c|}{ NPLR } & \multicolumn{1}{l|}{ LNTA } & \multicolumn{1}{c|}{ ROE } \\
\hline CAR & 1 & & & \\
\hline NPLR & -0.082 & 1 & & \\
\hline LNTA & 0.0276 & -0.051 & 1 & \\
\hline ROE & -0.0662 & -0.4078 & -0.0503 & 1 \\
\hline
\end{tabular}

From Tables 3 and 4, we see that the highest correlation between the NLPR and ROE variables is -0.4078 . According to researchers, the highest value of the correlation between the variables should be greater than 0.8 . Given this fact, we can conclude that the variables have no correlation between them.

The result of regression
To confirm the hypothesis presented, we have performed two regression analyzes.

- Hypothesis 1: concerns the relations bounded by CAR and NPLR and ROE of trading banks.

The first regression analysis was accomplished to test the first premise.

$R O E \mathrm{t}=\beta \mathrm{t}+\beta \mathrm{t} \times C A R \mathrm{t}+\beta \mathrm{t} \times N P L ! \mathrm{t}+\beta \mathrm{t} \times L N T A \mathrm{t}$

Table 5: Regression results for hypothesis 1

\begin{tabular}{|l|r|r|r|r|r|c|}
\hline Variable & \multicolumn{1}{|c|}{ Coef. } & Std.Err. & \multicolumn{1}{c|}{ T } & P > (t) & 95\% & R2 \\
\hline CAR & -0.26 & 0.18 & -1.6 & 0.125 & $-0.60,0.81$ & 0.1067 \\
\cline { 1 - 6 } NPL & -1.46 & 0.25 & -5.65 & 0.001 & $-1.95,-0.92$ & \\
\cline { 1 - 5 } LNTA & -0.73 & -0.75 & -1.22 & 0.275 & $-2.10,0.65$ & \\
\cline { 1 - 5 } Constant & 18.39 & 4.81 & 3.78 & 0 & $9.30,27.65$ & \\
\hline
\end{tabular}

Source: Authors' calculation

The regression analysis results in Table 6 show that the CAR value is 0.125 and the NPL is 0.001 . For the linkage between the two variables to be statistically significant, the p-value should not be greater than 0.05 . The first part of the hypothesis shows that CAR and ROE have no statistically significant relationship because $p=$ 0.125 , which is greater than the threshold for 
rejection of $\mathrm{p}=0.05$. Based on this result, it can be said that the effect of these two variables is caused by chance. Regarding the second part of the hypothesis, NLPR and ROE have a positive relationship where $\mathrm{p}=0.001$. This part of the hypothesis is accepted, and we can conclude that the effect of these two variables is not caused by chance. Referring to the table, we see that for LNTA (bank size) $\mathrm{p}=0.275$, and we reject the hypothesis that there is no significant relationship between these two variables. This seems to be interesting regarding the next research about the LNTA, as part of risk management linked to CAR.

- Hypothesis 2

Analysis of second regression - regression II was done to test the second hypothesis.

The formula for the second hypothesis is:

$R O A \mathrm{t}=\beta \mathrm{t}+\beta \mathrm{t} \times C A R \mathrm{t}+\beta \mathrm{t} \times N P L R \mathrm{t} !+\mathrm{t} \times L N T A \mathrm{t}$

$\mathrm{H} 2$ - There is a linkage betwixt CAR, NLP, and ROA of trading banks.

Table 6: Results of regression for second hypothesis - hypothesis 2

\begin{tabular}{|l|r|r|r|r|r|r|}
\hline Variables & \multicolumn{1}{|c|}{ Coef. } & \multicolumn{1}{c|}{ Std. Err } & \multicolumn{1}{c|}{$\mathrm{t}$} & $\mathrm{P}>(\mathrm{t})$ & \multicolumn{1}{c|}{ 95\% } & R2 \\
\hline & & & & & confidence interval & \\
\hline CAR & -0.008 & -0.019 & -0.74 & 0.475 & $-0.034,0.211$ & 0.0987 \\
\cline { 1 - 6 } NLPR & 0.066 & -0.025 & -4.15 & 0.002 & $0.083,-0.003$ & \\
\hline LNTA & -0.123 & 0.037 & -3.25 & 0.005 & $-0.182,-0.040$ & \\
\cline { 1 - 5 } Constant & -0.347 & 0.39 & -0.72 & 0 & $0.219,1.443$ & \\
\hline
\end{tabular}

Source: Authors' calculation

Based on the regression analysis result, we see that CAR has a p-value of 0.475 while NLP has a p-value of 0.002 . Whether a hypothesis is accepted or rejected, the value of the p-value must be $5 \%$. Based on our analysis, we conclude, in relation to the first section of the hypothesis, there is no significant association between CAR and ROA, and we can say that this part of the hypothesis is rejected. We are able to conclude that the effect between these can be attributed to chance. Regarding the second part of the hypothesis, NLPR and ROA have statistical significance, and we are able to exclude the possibility that this effect is not caused by chance.

Other studies have similar results, such as that by Hosna et al. (2009) concerning Swedish banks that used ROE as a dependent variable and CAR and NPLR as independent variables. Their findings revealed that NPLR had a negative effect, while CAR had a positive effect, but in other respects, these were unconvincing. It should also be noted that Aliu and Sahiti (2016), in their study of Kosovo banks, concluded that the quality of NLPRs affects Kosovo's commercial banks' liquidity.

\section{Granger causality test result}

The Granger Causality test result shows there is no relationship between the variables because the variables have a greater value than 0.05 of probability. This result is also based on the findings of the Pearson correlation.

Table 7: Results of Granger causality test

\begin{tabular}{|l|r|r|c|}
\hline & \multicolumn{1}{|c|}{ Obs } & \multicolumn{1}{|c|}{ F-Statistic } & \multicolumn{1}{c|}{ Pprob } \\
\hline CAR does not Granger Cause ROE & 315 & 0.06765 & 0.8966 \\
\hline NLPR does not Granger Cause ROE & 315 & 0.97832 & 0.3253 \\
\hline CAR does not Granger Cause ROA & 315 & 1.43674 & 0.2742 \\
\hline NLPR does not Granger Cause ROA & 315 & 2.34312 & 0.1932 \\
\hline CAR does not Granger Cause LNTA & 315 & 0.78459 & 0.7835 \\
\hline
\end{tabular}

Source: Authors' calculation 


\section{CONCLUSIONS}

The study's scope is to investigate how risk management is done benefit by trading banks in Western countries. As profit-related indicators, we have considered ROA and ROE, and as indicators of risk management, we used CAR and NPL. We used the SPSS program to process our data and tested the two hypotheses presented in the study. Based on our analysis of correlation and regression, we conclude that commercial banks in Western countries have good liquidity-risk management.

Our empirical findings are that CARs do not have any statistically significant relationship with ROE and ROA, which may be a topic of discussion for future researchers. NLPR has a negative relationship with ROE and ROA. This is in line with other studies in the field. Based on the study, we can conclude that the higher the non-performing loans, the lower the liquidity and capital investment. Managers should pay special attention to the management of these loans by evaluating them precisely. Based on this research, credit risk seems to be a significant indicator of commercial banks in Western Balkans countries. Raising these determinants can result in increased profitability of commercial banks.

\section{REFERENCES}

Aliu, M., \& \& Sahiti, A. (2016). The Effect of Credit Risk Management on Banks' Profitability in Kosovo. European Journal of Economic Studies, 18(4), 492-515. https://doi.org/10.13187/es.2016.18.492

Afroz, F. (2019). MTB - Internship Report On Credit Risk Management Policies of Bank Asia Limited, 3(3), 1-124. Retrieved from http://dspace.uiu.ac.bd/handle/52243/738

Fan, L., \& Shaffer, S. (2004). Efficiency versus risk in large domestic US banks. Managerial Finance, 309), 1-19. https://doi.org/10.1108/03074350410769245

Fumo, N., \& Rafe Biswas, M. A. (2015). Regression analysis for prediction of residential energy consumption. Renewable and Sustainable Energy Reviews. https://doi.org/10.1016/j.rser.2015.03.035

Haselmann, R., \& Wachtel, P. (2006). Bank risk and bank management in transition : A progress report on the EBRD banking environment and performance survey. New York.

Hassan Al-Tamimi, H. A., \& Mohammed Al-Mazrooei, F. (2007). Banks' risk management: a comparison study of UAE national and foreign banks. The Journal of Risk Finance, 8(4), 394-409.

https://doi.org/10.1108/15265940710777333

Hosna, A., Manzura, B., \& Sun, J. (2009). Credit Risk Management and Profitability in commercial banks in Sweden. Master Degree Project 2009:36.

Khambata, D., \& Bagdi, R. R. (2003). Off-balancesheet credit risk of the top 20 Japanese banks. Journal of Banking Regulation. https://doi.org/10.1057/palgrave.jbr.2340157

Mathuva, D. M. (2009). Capital Adequacy, Cost Income Ratio and the Performance of Commercial Banks: The Kenyan Scenario. The International Journal of Applied Economics and Finance. https://doi.org/10.3923/ijaef.2009.35.47

Niinimäki, J. P. (2004). The Effects of Competition on Banks' Risk Taking. Journal of Economics/Zeitschrift Fur Nationalokonomie, 81(3), 199-222. https://doi.org/10.1007/s00712-003-0027-9

Nguyen, C. V., Khoi, P. D., \& Williams, M. J. (2017). The transmission mechanism of Russian central bank's countercyclical monetary policy since 2011: Evidence from the interest rate pass-through. Journal of Eastern European and Central Asian Research. https://doi.org/10.15549/jeecar.v4i2.165

Oldfield, G. S., \& Santomero, A. M. (1997). The place of risk management in financial institutions. Sloan Management Review.

Pandis, N. (2016). Multiple linear regression analysis. American Journal of Orthodontics and Dentofacial Orthopedics, 149 (4), 581. https://doi.org/10.1016/j.ajodo.2016.01.012

Sakilu, O. B., \& Kibret, B. G. (2015). Determinants of the financial performances of commercial banks in Ethiopia: From internal corporate governance practices perspective. Journal of Eastern European and Central Asian Research. https://doi.org/10.15549/jeecar.v2i1.82 
Sobolieva-Tereshchenko, O., \& Zhukova, Y. (2020). Stress testing of the banking systems: Approach of ukraine. Journal of Eastern European and Central Asian Research, 72 ), 205-218. https://doi.org/10.15549/jeecar.v7i2.358

The World Bank. (2018). Data: World Bank Country and Lending Groups.

Vovchak, O., Reverchuk, S., Rudevska, V., \& Yaroslav, K. (2019). Bank business modeling and levels of non-performing loans: Perspectives of interaction risk factors in Ukraine. Journal of Eastern European and Central Asian Research. https://doi.org/10.15549/jeecar.v6i2.391

Yuqi, L. (2007). Determinants of Bank's Profitability and its Implication on Risk Management Practices: Panel Evidence from the UK in the Period 1999-2006. Panel Evidence from the UK, University of Nottingham.

\section{ABOUT THE AUTHORS}

Arbana Sahiti, email: arbana.sahiti@uni-pr.edu

Dr. Sevdie Alshiqi is the Economics Faculty at the University of Prishtina "Hasan Prishtina", Republic of Kosovo

Dr. Arbana Sahiti, as corresponding author, is the Economics Faculty at the University of Prishtina "Hasan Prishtina", Republic of Kosovo 